\title{
The use of mobile health interventions for gestational diabetes mellitus: a descriptive literature review
}

\author{
Maryam Zahmatkeshan ', Somayyeh Zakerabasali ${ }^{2}$, Mojtaba Farjam ${ }^{1,3}$, Yousef Gholampour ${ }^{4}$, Maryam Seraji $^{5}$, Azita Yazdani $^{2 *}$
}

\section{Author Affiliations:}

1. Noncommunicable Diseases Research Center, School of Medicine, Fasa University of Medical Sciences, Fasa, Iran

2. Department of Health Information Management, Health Human Resources Research Center, School of Management and Information Sciences,

Shiraz University of Medical Sciences, Shiraz, Iran

3. Clinical Research Development Unit, Valie-Asr Hospital, Fasa University of Medical Sciences, Fasa, Iran

4. Medical School, Fasa University of Medical Sciences, Fasa, Iran

5. Health Promotion Research Center, Zahedan University of Medical Sciences, Zahedan, Iran

\section{ABSTRACT}

This study attempted to review the evidence for or against the effectiveness of mobile health (m-health) interventions on health outcomes improvement and/or gestational diabetes mellitus (GDM) management. PubMed, Web of Science, Scopus, and Embase databases were searched from 2000 to 10 July 2018 to find studies investigating the effect of m-health on GDM management. After removing duplications, a total of 27 articles met our defined inclusion criteria. m-health interventions were implemented by smartphone, without referring to its type, in $26 \%(7 / 27)$ of selected studies, short message service (SMS) in 14.9\% (4/27), mobile-based applications in 33.3\% (9/27), telemedicine-based on smartphones in 18.5\% (5/27), and SMS reminder system in $7.1 \%(2 / 27)$. Most of the included studies $(n=23)$ supported the effectiveness of m-health interventions on GDM management and $14.3 \%(n=4)$ reported no association between m-health interventions and pregnancy outcomes. Based on our findings, m-health interventions could enhance GDM patients' pregnancy outcomes. A majority of the included studies suggested positive outcomes. M-health can be one of the most prominent technologies for the management of GDM.

KEYWORDS: m-health, gestational diabetes mellitus, gestational diabetes mellitus.

\author{
* Corresponding Author: \\ Azita Yazdani, Assistant Professor, \\ Department of Health \\ Information Management, Health \\ Human Resources Research \\ Center, School of Management \\ and Information Sciences, Shiraz \\ University of Medical Sciences, \\ Shiraz, Iran. \\ Phone: 989171530846 \\ E-mail: A_yazdani@sums.ac.ir \\ DOI
}

10.25122/jml-2020-0163

\section{Dates}

Received: 14 October 2020

Accepted: 2 April 2021

\section{INTRODUCTION}

High-risk complications are estimated to occur in 10 percent of pregnancies, and the evidence reveals the growing rate of high-risk pregnancies [1]. One of the most common complications that can occur during pregnancy is gestational diabetes mellitus (GDM) [2, 3], accounting for more than $80 \%$ of diabetes cases during pregnancy [2]. GDM is found in $2 \%$ to $16 \%$ of all pregnancies [4], affecting about 150,000 pregnancies annually [5, 6]. GDM affects both mother and child [7] and poses the mother and child at risk of preeclampsia, cesarean delivery, congenital anomalies, fetal macrosomia, and the later development of type 2 diabetes [8]. Given the increasing prevalence of GDM, new challenges are developed for health care professionals in antenatal care [9]. High-risk pregnancies are often managed by hospitalizing the patients for days and sometimes even weeks, leading to an increased financial burden [10] and stress for the patients [11]. By proper monitoring, the risk and the disease costs will be reduced for a pregnant woman [12-14].

The recent advances in medical devices coupled with the development of intelligent sensors, Internet of Things (IoT), efficient telecommunication and information based smart decision support system (DSS), and m-health technologies have unlocked the door of ample opportunities for patients' remote monitoring and health parameters tracking, thus enabling a paradigm shift in maternal health care [13, 15]. 


\section{JOURNAL of MEDICINE and LIFE}

Recently, the dramatic advancements of information and communication technologies (ICTs) in health care have led to the development of m-health, creating substantial improvement in the provision of health services [16]. M-health interventions have been developed along with technological advances [17]. The widespread adoption of mobile phone technologies offers a promising opportunity to promote diabetes care and self-management [18-20] by creating an active interaction between patients and healthcare professionals [9, 20].

The increasing storage capacity of mobile phones along with Wi-Fi accessibility represent the opportunity to offer mobile applications with the capabilities of tracking one or more health parameters such as glucose, diet, exercise and medication [19, 21-25]. Mobile phone text messaging has enabled the provision of timely access to health advice, prompt self-monitoring, and individual's education about preventive health care services [26]. Immediate delivery of short messages or direct calls to individuals is facilitated by mobile phone. Patients can be reminded over the cell phone at the time of the blood glucose measurement or another event (medication), leading to improvement of glycated hemoglobin $(\mathrm{HbAlc})$ levels and self-care regarding diet, medication, and exercise [20]. Following the emergent of $\mathrm{m}$-health interventions in GDM, the development and evaluation of individual interventions have attracted more attention by the researchers. The previous systematic reviews either have focused on the effectiveness of m-health interventions [4, 16, 27-34] or a single condition [35-38]. However, minimal evidence has been provided on healthcare utilization or cost analyses.

Therefore, the present study was attempted to systematically review the effectiveness of GDM-related m-health interventions from different perspectives. Recently, m-health has been introduced as a novel approach in GDM management. The delivery of face-to-face support has been examined in previous research; however, little is known about the implementation of m-health as a possible alternative form of health service delivery for GDM patients. The aim of this descriptive literature review was to assess the evidence provided for or against the efficacy of m-health in GDM monitoring.

\section{MATERIAL AND METHODS}

\section{Search strategy}

We performed this study according to the Preferred Reporting Items for Systematic Reviews and Meta-Analysis (PRISMA) [39]. PubMed, Web of Science, Embase, and Scopus databases were searched from 2000 to July 10, 2018. The searches were not limited by language.

The searches were done using the keywords of mobile health (m-health) and GDM. For the purpose of this review, m-health was defined as the use of technology to provide healthcare for patients with GDM using the short message service (SMS), mobile applications, and telemedicine systems based on smartphones.

The stages for building the search query for the PubMed database are shown in Table 1. With respect to the instructions provided for each database, equivalent searches were then performed. Findings of each study were analyzed, relevant information was extracted, and the obtained data were synthesized. The objectives and findings of each study are summarized in Table 2.

\section{Inclusion and exclusion criteria}

In this study, all articles evaluated the effectiveness of $\mathrm{m}$-health on GDM management by using m-health tools such as telemedicine systems based on smartphones, m-Health, short message service (SMS), and mobile applications were included. Reviews and unpublished dissertations, commentaries, opinion papers, editorials, summaries were not considered. Studies that used telemedicine intervention without a mobile phone or those that reported functions and implementation of the interventions unclearly or presented descriptions of information technology were excluded.

\section{Table 1. PubMed search query.}

\begin{tabular}{|c|c|}
\hline $\begin{array}{l}\text { Step in search } \\
\text { strategy }\end{array}$ & Search term \\
\hline 1 & $\begin{array}{c}\text { mobile health OR mobile OR mhealth OR m-health OR mobile technology OR smartphone OR mobile phone OR cell phone } \\
\text { OR app OR applications OR short message service OR short message OR text message OR SMS }\end{array}$ \\
\hline 2 & $\begin{array}{r}\text { (Diabetes, Pregnancy-Induced) OR (Diabetes, Pregnancy Induced) OR (Pregnancy-Induced Diabetes) OR (Gestational Diabe- } \\
\text { tes) OR (Diabetes Mellitus, Gestational) OR (Gestational Diabetes Mellitus) }\end{array}$ \\
\hline 3 & 2000/01/01:2018/11/15[dp] \\
\hline 4 & 1 AND 2 AND 3 \\
\hline
\end{tabular}




\section{JOURNAL of MEDICINE and LIFE}

Table 2. Reviewed papers' characteristics and $m$-health interventions and results from studies.

\begin{tabular}{|c|c|c|c|c|c|c|c|}
\hline \multirow[b]{2}{*}{ Author, Year } & \multirow[b]{2}{*}{ Study objective } & \multirow[b]{2}{*}{ Study design } & \multicolumn{4}{|c|}{ Type of mHealth medium } & \multirow[b]{2}{*}{$\begin{array}{c}\text { Outcome } \\
\text { (main findings) }\end{array}$} \\
\hline & & & Smartphone & $\begin{array}{l}\text { Telemedicine } \\
\text { system } \\
\text { based on } \\
\text { smartphones }\end{array}$ & SMS & App & \\
\hline $\begin{array}{l}\text { Ping Yang, } \\
2018 \text { [44] }\end{array}$ & $\begin{array}{l}\text { The effect } \\
\text { of WeChat } \\
\text { platform-based } \\
\text { treatment on the } \\
\text { risk of perinatal } \\
\text { complications } \\
\text { among women } \\
\text { with GDM. }\end{array}$ & $\begin{array}{l}\text { Non-Randomized } \\
\text { Study }\end{array}$ & & * & & & $\begin{array}{c}\text { WeChat } \\
\text { platform-based } \\
\text { treatment could } \\
\text { effectively reduce } \\
\text { FBG and } 2 \mathrm{~h} \\
\text { PBG levels and } \\
\text { improve pregnancy } \\
\text { outcomes. }\end{array}$ \\
\hline Skar, 2018 [45] & $\begin{array}{l}\text { The effect of } \\
\text { smartphone app } \\
\text { (the Pregnant+ } \\
\text { app) on controlling } \\
\text { blood glucose } \\
\text { levels and } \\
\text { receiving health } \\
\text { and nutrition } \\
\text { information in } \\
\text { women with GDM. }\end{array}$ & RCT & & & & * & $\begin{array}{l}\text { Smartphone app } \\
\text { could assist women } \\
\text { with GDM to control } \\
\text { their blood glucose } \\
\text { and increased } \\
\text { their confidence } \\
\text { regarding } \\
\text { self-management. }\end{array}$ \\
\hline $\begin{array}{l}\text { Miremberg, } \\
2018 \text { [46] }\end{array}$ & $\begin{array}{l}\text { The impact of a } \\
\text { smartphone-based } \\
\text { daily feedback and } \\
\text { communication } \\
\text { platform on } \\
\text { GDM patients' } \\
\text { compliance, } \\
\text { glycemic control, } \\
\text { pregnancy } \\
\text { outcome, and } \\
\text { satisfaction }\end{array}$ & RCT & * & & & & $\begin{array}{l}\text { Smartphone-based } \\
\text { technology could } \\
\text { enhance the } \\
\text { adherence to } \\
\text { self-performed BG } \\
\text { monitoring and } \\
\text { glycemic control } \\
\text { parameters such } \\
\text { as mean blood } \\
\text { glucose, off-target } \\
\text { measurements, and } \\
\text { the need for insulin } \\
\text { treatment. }\end{array}$ \\
\hline Mackillo, 2018 [47] & $\begin{array}{l}\text { The use of a } \\
\text { mobile } \\
\text { phone-based } \\
\text { real-time } \\
\text { blood glucose } \\
\text { management } \\
\text { system to control } \\
\text { GDM patients' } \\
\text { blood glucose. }\end{array}$ & RCT & * & & & & $\begin{array}{c}\text { Remote monitoring } \\
\text { of blood glucose is } \\
\text { safe in women with } \\
\text { GDM. }\end{array}$ \\
\hline Rigla, 2018 [48] & $\begin{array}{l}\text { The efficacy of } \\
\text { smart mobile } \\
\text { telemedicine in } \\
\text { monitoring blood } \\
\text { glucose of GDM } \\
\text { patients. }\end{array}$ & Pilot Study & & * & & & $\begin{array}{l}\text { This decision } \\
\text { support system was } \\
\text { a feasible and } \\
\text { well-accepted } \\
\text { system for } \\
\text { monitoring GDM. }\end{array}$ \\
\hline Kennelly, 2018 [42] & $\begin{array}{l}\text { The impact of a } \\
\text { healthy lifestyle } \\
\text { package using } \\
\text { smartphone } \\
\text { application } \\
\text { technology on the } \\
\text { prevalence of GDM } \\
\text { in overweight and } \\
\text { obese women. }\end{array}$ & RCT & & & & * & $\begin{array}{c}\text { This intervention } \\
\text { could not decrease } \\
\text { the prevalence of } \\
\text { GDM. }\end{array}$ \\
\hline
\end{tabular}


JOURNAL of MEDICINE and LIFE

\begin{tabular}{|c|c|c|c|c|c|}
\hline Johnson, 2018 [49] & $\begin{array}{l}\text { The effect of } \\
\text { short messaging } \\
\text { reminders on } \\
\text { diabetes } \\
\text { self-management } \\
\text { in women with } \\
\text { GDM }\end{array}$ & RCT & * & & $\begin{array}{l}\text { The use of daily } \\
\text { text messages } \\
\text { was acceptable } \\
\text { for patients with } \\
\text { GDM. In addition, an } \\
\text { overall satisfaction } \\
\text { with the messages } \\
\text { and willingness to } \\
\text { use the messages in } \\
\text { future pregnancies } \\
\text { and to recommend } \\
\text { the messages to } \\
\text { friends with GDM } \\
\text { were obtained. }\end{array}$ \\
\hline $\begin{array}{l}\text { Garnweidner-Holme, } \\
2018 \text { [9] }\end{array}$ & $\begin{array}{l}\text { The usefulness of } \\
\text { culture-sensitive } \\
\text { pregnant } \\
\text { application } \\
\text { for pregnant } \\
\text { women with } \\
\text { GDM according } \\
\text { to health care } \\
\text { professionals' } \\
\text { perspectives }\end{array}$ & $\begin{array}{l}\text { Qualitative } \\
\text { study }\end{array}$ & & * & $\begin{array}{l}\text { M-Health } \\
\text { intervention was } \\
\text { a useful tool to } \\
\text { improve the care } \\
\text { provided by health } \\
\text { care professionals } \\
\text { to women with } \\
\text { GDM. }\end{array}$ \\
\hline Peleg, 2017 [50] & $\begin{array}{l}\text { The MobiGuide's } \\
\text { feasibility and } \\
\text { potential impacts } \\
\text { on patients and } \\
\text { care providers } \\
\text { using two various } \\
\text { clinical domains. }\end{array}$ & Pilot Study & & * & $\begin{array}{l}\text { This system has } \\
\text { provided multiple } \\
\text { benefits for } \\
\text { both patients } \\
\text { and physicians } \\
\text { and increase the } \\
\text { patients' sense } \\
\text { of safety and } \\
\text { involvement. }\end{array}$ \\
\hline Peleg, 2017 [51] & $\begin{array}{l}\text { The system's } \\
\text { feasibility and } \\
\text { potential impacts } \\
\text { on patients and } \\
\text { care providers } \\
\text { using two various } \\
\text { clinical domains. }\end{array}$ & Pilot Study & & * & $\begin{array}{l}\text { MobiGuide's is } \\
\text { feasible for patients } \\
\text { and clinicians and } \\
\text { has led to high } \\
\text { compliance to } \\
\text { self-measurement } \\
\text { recommendations } \\
\text { and enhance the } \\
\text { satisfaction of } \\
\text { patients and care } \\
\text { providers. }\end{array}$ \\
\hline $\begin{array}{l}\text { McLean, A. } \\
2017 \text { [41] }\end{array}$ & $\begin{array}{l}\text { The efficacy } \\
\text { of real-time } \\
\text { smartphone data } \\
\text { in improving } \\
\text { clinical } \\
\text { management } \\
\text { and outcomes of } \\
\text { women at GDM } \\
\text { risk }\end{array}$ & Pilot Study & * & & $\begin{array}{l}\text { Real-time individual } \\
\text { health and sensor } \\
\text { data can be readily } \\
\text { collected and } \\
\text { analyzed efficiently } \\
\text { while confidentiality } \\
\text { is maintained; } \\
\text { however, improved } \\
\text { prediction of GDM } \\
\text { was not obtained. }\end{array}$ \\
\hline
\end{tabular}




\section{JOURNAL of MEDICINE and LIFE}

\begin{tabular}{|c|c|c|c|c|c|c|}
\hline $\begin{array}{l}\text { Nicholson, } \\
2016 \text { [52] }\end{array}$ & $\begin{array}{l}\text { The efficacy of } \\
\text { a web-based } \\
\text { pregnancy and } \\
\text { postpartum } \\
\text { behavioral } \\
\text { intervention in } \\
\text { contributing } \\
\text { women with } \\
\text { GDM to control } \\
\text { weight and } \\
\text { glucose during } \\
\text { pregnancy and } \\
\text { the postpartum } \\
\text { period. }\end{array}$ & RCT & & * & & $\begin{array}{l}\text { The web-based } \\
\text { behavioral } \\
\text { intervention } \\
\text { coupled with text } \\
\text { messages and } \\
\text { emails and tailored } \\
\text { to the needs of } \\
\text { women with GDM } \\
\text { is feasible and } \\
\text { well received by } \\
\text { participants. This } \\
\text { study also shows } \\
\text { that GooDMoms } \\
\text { can change the } \\
\text { current paradigm of } \\
\text { pregnancy care for } \\
\text { women with GDM. }\end{array}$ \\
\hline Marko, 2016 [53] & $\begin{array}{l}\text { The feasibility } \\
\text { of remote } \\
\text { monitoring of } \\
\text { patients for } \\
\text { prenatal care } \\
\text { using a mobile } \\
\text { phone application } \\
\text { and connected } \\
\text { digital devices. }\end{array}$ & $\begin{array}{l}\text { Prospective } \\
\text { Observational } \\
\text { Study }\end{array}$ & & & $*$ & $\begin{array}{l}\text { This intervention is } \\
\text { feasible for prenatal } \\
\text { care. }\end{array}$ \\
\hline $\begin{array}{l}\text { Wickramasinghe, } \\
2015 \text { [54] }\end{array}$ & $\begin{array}{l}\text { The usefulness of } \\
\text { mobile technology } \\
\text { for supporting } \\
\text { and enabling } \\
\text { superior diabetes } \\
\text { monitoring and } \\
\text { management. }\end{array}$ & Case Study & * & & & $\begin{array}{l}\text { Mobile technology } \\
\text { is an appropriate } \\
\text { choice to minimize } \\
\text { costs and provide } \\
\text { high-quality care. }\end{array}$ \\
\hline Jo, 2015 [55] & $\begin{array}{l}\text { The efficacy of } \\
\text { an application } \\
\text { providing tailored } \\
\text { recommendations } \\
\text { based on user's } \\
\text { lifestyle and } \\
\text { clinical data. }\end{array}$ & $\begin{array}{l}\text { Development } \\
\text { and Test Study }\end{array}$ & & & * & $\begin{array}{l}\text { The GDM } \\
\text { management } \\
\text { knowledge } \\
\text { and tailored } \\
\text { recommendations } \\
\text { provided in } \\
\text { this study were } \\
\text { beneficial for } \\
\text { managing GDM. }\end{array}$ \\
\hline $\begin{array}{l}\text { Van Ryswyk, } \\
2015 \text { [40] }\end{array}$ & $\begin{array}{l}\text { The effect of SMS } \\
\text { reminder system } \\
\text { on postpartum } \\
\text { oral glucose } \\
\text { tolerance test, } \\
\text { fasting plasma } \\
\text { glucose, and } \\
\text { HbA1c completion. }\end{array}$ & RCT & & * & & $\begin{array}{l}\text { The SMS } \\
\text { reminder system } \\
\text { cannot enhance } \\
\text { postpartum OGTT, } \\
\text { fasting plasma } \\
\text { glucose, or HbA1c } \\
\text { completion. }\end{array}$ \\
\hline $\begin{array}{l}\text { Mohd Suan, } \\
2015 \text { [56] }\end{array}$ & $\begin{array}{l}\text { The prevalence } \\
\text { and characteristics } \\
\text { of patients who } \\
\text { did and did not } \\
\text { return for the } \\
\text { OGTT and the } \\
\text { reasons provided } \\
\text { by women for } \\
\text { failure to return } \\
\text { for the OGTT test. }\end{array}$ & $\begin{array}{l}\text { Cross-sectional } \\
\text { Study }\end{array}$ & & * & & $\begin{array}{l}\text { The prevalence } \\
\text { of women who } \\
\text { returned for the } \\
\text { postpartum diabetic } \\
\text { screening test was } \\
\text { high. This study also } \\
\text { provides valuable } \\
\text { insights into several } \\
\text { obstacles that } \\
\text { render the return } \\
\text { for the glucose } \\
\text { tolerance test. }\end{array}$ \\
\hline
\end{tabular}




\section{JOURNAL of MEDICINE and LIFE}

Table 2. Continued.

\begin{tabular}{|c|c|c|c|c|}
\hline Hirst, 2015 [57] & $\begin{array}{l}\text { Women's } \\
\text { satisfaction using } \\
\text { the GDM-health } \\
\text { system and their } \\
\text { attitudes toward } \\
\text { their diabetes } \\
\text { care. }\end{array}$ & Pilot Study & * & $\begin{array}{l}\text { GDM-health was } \\
\text { acceptable and } \\
\text { convenient for a } \\
\text { large proportion of } \\
\text { women. }\end{array}$ \\
\hline
\end{tabular}

The efficacy of smartphones on

Teoh, 2014 [58]

GDM monitoring
among Australian
women.
The use of smartphones to support GDM self-management facilitates superior monitoring and management of GDM and supports the accountable care paradigm.

\begin{tabular}{|c|c|c|c|c|c|}
\hline Kaplan, 2014 [59] & $\begin{array}{c}\text { Efficacy of a } \\
\text { mobile application } \\
\text { and web-based } \\
\text { system in } \\
\text { promoting } \\
\text { self-management } \\
\text { of women with } \\
\text { GDM. }\end{array}$ & Pilot Study & & * & $\begin{array}{c}\text { This mobile } \\
\text { application and } \\
\text { web-based system } \\
\text { can promote } \\
\text { self-management of } \\
\text { women with GDM }\end{array}$ \\
\hline Grabosch, 2014 [60] & $\begin{array}{l}\text { The feasibility of } \\
\text { a text message } \\
\text { reminder system } \\
\text { for pregnant } \\
\text { women with } \\
\text { diabetes from } \\
\text { a low-income } \\
\text { population, and } \\
\text { its impact on } \\
\text { adherence to a } \\
\text { diabetes care } \\
\text { regimen and } \\
\text { subsequent } \\
\text { glycemic control }\end{array}$ & $\mathrm{RCT}$ & * & & $\begin{array}{l}\text { The text message } \\
\text { reminder system } \\
\text { is feasible for } \\
\text { pregnant women } \\
\text { with diabetes } \\
\text { from a low-income } \\
\text { population and } \\
\text { Text4baby can } \\
\text { be used as an } \\
\text { educational tool to } \\
\text { improve outcomes } \\
\text { in women with } \\
\text { diabetes. }\end{array}$ \\
\hline $\begin{array}{l}\text { Shivanath, } \\
2014 \text { [61] }\end{array}$ & $\begin{array}{l}\text { The feasibility of } \\
\text { "Simple Telehealth" } \\
\text { for women } \\
\text { with gestational } \\
\text { diabetes, patients' } \\
\text { treatment } \\
\text { satisfaction with } \\
\text { this intervention, } \\
\text { and the economic } \\
\text { benefit of } \\
\text { this system in } \\
\text { conjunction with } \\
\text { routine antenatal } \\
\text { diabetes care. }\end{array}$ & Pilot Study & * & & $\begin{array}{l}\text { Short-term use of } \\
\text { "Simple Telehealth" } \\
\text { is associated with } \\
\text { high treatment } \\
\text { satisfaction levels } \\
\text { amongst patients } \\
\text { with GDM and some } \\
\text { economic benefits. }\end{array}$ \\
\hline Homko, 2012 [43] & $\begin{array}{l}\text { The impact of } \\
\text { an enhanced } \\
\text { telemedicine } \\
\text { system on } \\
\text { glucose control } \\
\text { and pregnancy } \\
\text { outcomes in } \\
\text { women with GDM. }\end{array}$ & $\mathrm{RCT}$ & * & & $\begin{array}{c}\text { Enhanced } \\
\text { telemedicine } \\
\text { monitoring system } \\
\text { increased contact } \\
\text { between women } \\
\text { with GDM and } \\
\text { their healthcare } \\
\text { providers but } \\
\text { did not influence } \\
\text { on pregnancy } \\
\text { outcomes. }\end{array}$ \\
\hline
\end{tabular}




\section{JOURNAL of MEDICINE and LIFE}

\begin{tabular}{|c|c|c|c|c|}
\hline Shea, 2011 [62] & $\begin{array}{l}\text { The effect of a } \\
\text { reminder system } \\
\text { on screening rates. }\end{array}$ & $\mathrm{RCT}$ & * & $\begin{array}{l}\text { Reminders can be } \\
\text { an effective method } \\
\text { for reinforcing } \\
\text { guidelines for } \\
\text { postpartum } \\
\text { diabetes screening. }\end{array}$ \\
\hline
\end{tabular}

$\begin{array}{lc} & \text { The feasibility of } \\ & \text { a telemedicine } \\ & \text { system based on } \\ & \text { Internet and a } \\ & \text { short message } \\ \text { P'erez-Ferre, } & \text { service for } \\ 2010[63] & \text { pregnant women } \\ \text { with GDM and } \\ \text { its influence on } \\ \text { their delivery } \\ \text { and neonatal } \\ \text { outcomes. }\end{array}$

RCT

A telemedicine system can be a useful tool in the treatment of GDM patients. This study suggests this intervention as a complement to conventional outpatient clinic visits, especially in cases requiring tighter glycemic

control or with difficulties in accessing to medical center.

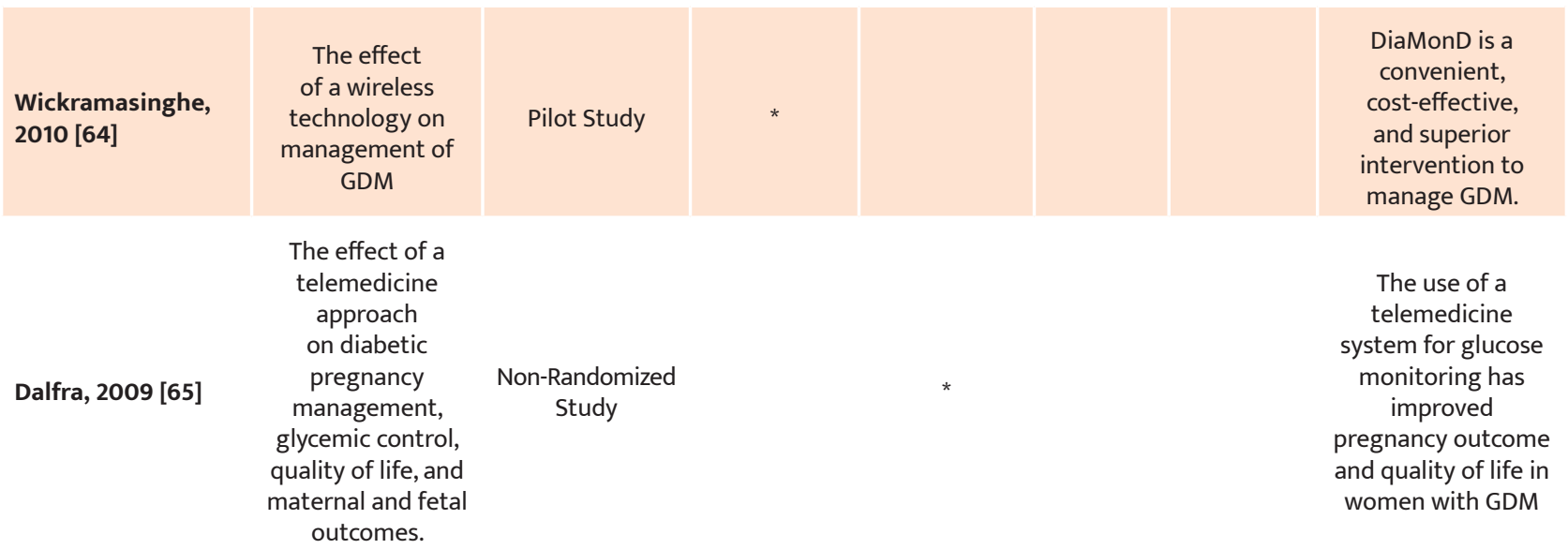

BG - blood glucose; FBG - fasting blood glucose; GDM - gestational diabetes mellitus; PBG - plasma blood glucose; RCT - randomized controlled trial; OGTT - oral glucose tolerance test.

\section{Selection of studies}

The selection of studies was done using four stages and based on the PRISMA flow diagram [39]. In the first stage (identification), studies identified through database searching were collated using the ENDNOTE software, and duplicates were omitted. In the second stage, two reviewers independently screened the titles and abstracts and removed irrelevant articles.

In the third stage, the full-text articles were independently evaluated for eligibility by the reviewers. In the fourth phase, two reviewers (MZ and ZK) compared and verified their findings. Any disagreement was resolved either through discussion or involving a third reviewer $(\mathrm{YGH})$. Data such as author names, year, study design, m-health intervention, outcome, and results were retrieved.

\section{RESULTS}

The article selection process is demonstrated in Figure 1. Observing our defined inclusion and exclusion criteria, twenty-seven studies were selected: twelve randomized controlled trials (RCTs); eight pilot studies; one cross-sectional study; two non-randomized controlled trials; one case study; one prospective observational study; one qualitative study; and one development and test study. The findings of the included studies concerning the efficacy of m-health interventions are summarized in Table 2. 


\section{JOURNAL of MEDICINE and LIFE}

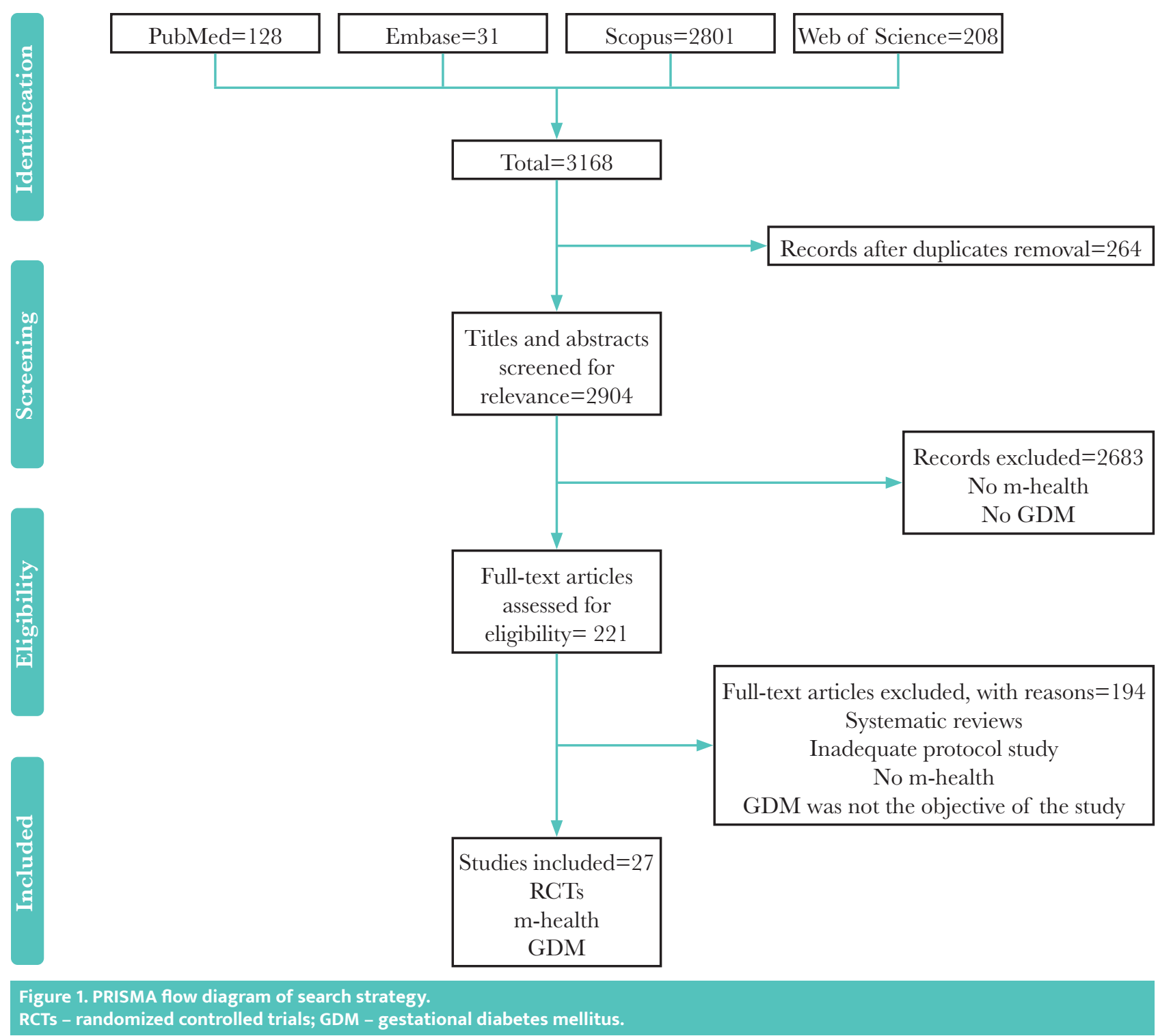

Among the 27 studies, 26\% (7/27) used a smartphone, without referring to its type, 14.9\% (4/27) used the SMS, 33.3\% (9/27) used mobile-based applications, 18.5\% (5/27) used telemedicine based on smartphones, and 7.1\% (2/27) used an SMS reminder system to investigate the efficacy of $m$-health interventions. Often, these studies supported the efficacy of $m$-health interventions $(n=4)$ [40-43].

\section{DISCUSSION}

To manage the disease and reduce the impact of chronic diseases, mobile health technologies can be helpful through the promotion of healthy behaviors $[15,66,67]$. These newly introduced technologies can be served as self-monitoring tools for individual patients [68-70] and can effectively enhance women's health [71].

Literature reviews have supported the efficacy of mobile-health interventions in the management of diabetes, proving to be beneficial for patients, especially GDM patients (to control their blood sugar levels [20, 31, 72-80].

In the current investigation, all findings in this regard are presented using a structure composed of four main categories of m-health intervention. These four branches are:

1. Smartphone-based: Smartphones support various aspects of care and patient-clinician interactions, provide high-quality care and support self-management of GDM [46, 47, 54, 57, 58,62]. The use of m-health can increase GDM patients' compliance with 


\section{JOURNAL of MEDICINE and LIFE}

lifestyle interventions and reduce future risk of type 2 diabetes mellitus and its sequelae [81]; however, this result was not supported by McLean et al. [41].

2. Smartphone-based telemedicine system: The impact of telemedicine interventions on GDM management has been investigated by many studies [43, 44, 48, 63, 65]. For instance, some studies have revealed the efficacy of telemedicine systems in monitoring glucose, improving pregnancy outcomes in women with GDM, and enhancing the quality of life of pregnant women with diabetes [44, 48, 63, 65]. These findings are in line with the results of other studies [4, 82, 83]. Nevertheless, Homko et al. [43] and Rasekaba et al. [82] found no association between a telemedicine system and pregnancy outcome improvement.

3. SMS and reminders: Studies have demonstrated the potential and essential role of SMS in altering the current paradigm of pregnancy care among women suffering from GDM $[49,52,61]$. Poorman et al. has supported the usefulness of SMS for maternal and infant health, especially for women who cannot outreach traditional communication methods [33]. Another study has revealed that Text4baby, a free mobile health information service delivering health-related SMS to pregnant and postpartum women, can enhance physical activity participation [84]. Given that most of the women suffering from GDM do not present for postpartum glucose testing despite recommendations, SMS can play an important role in increasing the postpartum return rate of women with GDM for diabetic screening tests [56]. However, Van Ryswyk et al. have not confirmed this finding [40].

4. Mobile application: Nine out of 27 selected studies have evaluated the efficacy of mobile applications. Eight have provided evidence supporting the usefulness of mobile applications for managing GDM [9, 45, 50, 51, 53, 55, 59, 64]. In contrast, Kennelly et al. [42], in line with two other studies [85, 86], have reported a lack of association between GDM management and mobile applications.

Patient satisfaction is one of the key factors in using mobile devices. We found that six studies $[46,47,49,51,57,61]$ have addressed the effect of m-health interventions on patient satisfaction, revealing higher satisfaction levels in pregnant women who received prenatal support via mobile phone. This finding is in line with the findings of previous studies [87, 88]. Kim et al. have also demonstrated the association between a high level of user satisfaction and using diabetes notepad application and the positive effect of this application on diabetes self-management [75].

Six studies have evaluated disease costs and reported that m-health interventions are economically cost-effective and can reduce disease costs $[49,51,54,58,61,64]$.

Considering the widespread use of mobile phones, various m-health tools have been developed for disease management and monitoring. However, the most effective tool for the management of GDM has not been reported yet. Therefore, in this systematic review, we have summarized the findings of previous studies on the effect of m-health interventions on GMD management.

The major limitation of this study is that only four databases were searched, which could have led to the missing of high-quality articles on m-health intervention for GDM. Published studies on GDM-related m-health interventions are increasing; however, the results are not consistent. Therefore, further evaluations are needed to obtain consistent conclusions regarding the usefulness of $\mathrm{m}$-health interventions for GDM management. Future research is recommended to evaluate m-health interventions using multiple functions or stages, especially those popular outside clinical practice.

\section{CONCLUSION}

Future research is recommended to evaluate m-health interventions using multiple functions or stages, especially those popular outside clinical practice. We consider that m-health intervention is one of the most important technologies for GDM management. Acknowledging the risks of gestational diabetes and the growing incidence of this disease, the risk and the disease costs could be reduced for a pregnant woman by proper monitoring. The widespread adoption of mobile phone technologies offers a promising opportunity to promote diabetes care and self-management by promoting healthy behaviors.

\section{ACKNOWLEDGMENTS}

\section{Conflict of interest}

The authors declare that there is no conflict of interest.

\section{REFERENCES}

1. Penders J, Altini M, Van Hoof C, Dy E. Wearable sensors for healthier pregnancies. Proceedings of the IEEE. 2015;103(2):179-91

2. Harrison TN, Sacks DA, Parry C, Macias M, Grant DSL, Lawrence JM. Acceptability of virtual prenatal visits for

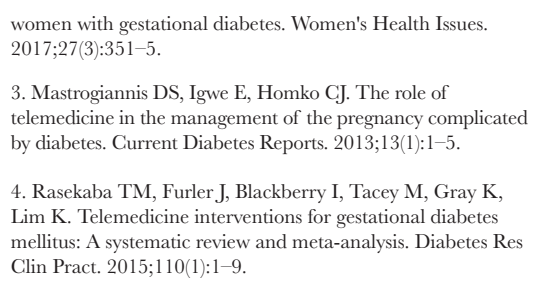

women with gestational diabetes. Women's Health Issues. 2017;27(3):351-5.

3. Mastrogiannis DS, Igwe E, Homko CJ. The role of telemedicine in the management of the pregnancy complicated by diabetes. Current Diabetes Reports. 2013;13(1):1-5.

4. Rasekaba TM, Furler J, Blackberry I, Tacey M, Gray K, Lim K. Telemedicine interventions for gestational diabetes mellitus: A systematic review and meta-analysis. Diabetes Res Clin Pract. 2015;110(1):1-9.

5. Homko CJ, Deeb LC, Rohrbacher K, Mulla W, Mastrogiannis D, Gaughan J, et al. Impact of a telemedicine system with automated reminders on outcomes in women with gestational diabetes mellitus. Diabetes Technology and Therapeutics. 2012;14(7):624-9.

6. Homko CJ, Santamore WP, Whiteman V, Bower M, Berger $\mathrm{P}$, Geifman-Holtzman O, et al. Use of an internet-based telemedicine system to manage underserved women with gestational diabetes mellitus. Diabetes Technology and Therapeutics. 2007;9(3):297-306. 


\section{JOURNAL of MEDICINE and LIFE}

7. Caballero-Ruiz E, Garcia-Saez G, Rigla M, Villaplana M, Pons B, Hernando ME. A web-based clinical decision suppor system for gestational diabetes: Automatic diet prescription and detection of insulin needs. Journal of Perinatal mMedicine. 2017;102:35-49.

8. Yogev Y, Ben-Haroush A, Chen R, Kaplan B, Phillip M, Hod M. Continuous glucose monitoring for treatment adjustment in diabetic pregnancies - a pilot study. Diabetic medicine. 2003;20(7):558-62

9. Garnweidner-Holme L, Andersen TH, Sando MW, Noll J, Lukasse M. Health Care Professionals' Attitudes Toward, and Experiences of Using, a Culture-Sensitive Smartphone App for Women with Gestational Diabetes Mellitus: Qualitative Study. Jmir Mhealth and Uhealth. 2018;6(5).

10. Vermeulen-Giovagnoli B, Peters C, Mischi M, van Pul C, Cottaar E, Oei S, Editors. The development of an obstetric tele-monitoring system. Engineering in Medicine and Biology Society (EMBC), $201537^{\text {th }}$ Annual International Conference of the IEEE; 2015: IEEE

11. Jezewski J, Pawlak A, Horoba K, Wrobel J, Czabanski R, Jezewski M. Selected design issues of the medical cyber-physical system for telemonitoring pregnancy at home. Microprocessors and Microsystems. 2016;46:35-43.

12. Chen W, Hu J, Bouwstra S, Oetomo SB, Feijs L. Senso integration for perinatology research. International Journal of Sensor Networks. 2010;9(1):38-49.

13. Kashem MA, Seddiqui M, Moalla N, Sekhari A, Ouzrou $\mathrm{Y}$ Review on Telemonitoring of Maternal Health care T. Review on Telemonitoring or Maternal Health care
Targeting Medical Cyber-Physical Systems. arXiv preprint Targeting Medical Cyber-P
arXiv:160707712. 2016.

14. Santhi V, Ramya K, Tarana A, Vinitha G. IOT based wearable health monitoring system for pregnant ladies using cc3200. International Journal of Advanced Research Methodology in Engineering and Technology, ISSN. 2017;2456:6446.

15. Free C, Phillips G, Galli L, Watson L, Felix L, Edwards P, et al. The effectiveness of mobile-health

technology-based health behaviour change or disease management interventions for health care consumers: systematic review PLoS medicine 2013:10(1)·e1001362.

16. Chen H, Chai Y, Dong L, Niu W, Zhang P. Effectiveness and appropriateness of mhealth interventions for maternal and child health: Systematic review. Journal of Medical Internet Research. 2018;20(1).

17. O'Brien CM, Cramp C, Dodd JM. Delivery of Dietary and Lifestyle Interventions in Pregnancy: Is it Time to Promote the Use of Electronic and Mobile Health Technologies? Seminars in Reproductive Medicine. 2016;34(2):e22-e7.

18. Garabedian LF, Ross-Degnan D, Wharam JF. Mobile Phone and Smartphone Technologies for Diabetes Care and Self-Management. Current Diabetes Reports. 2015;15(12).

19. El-Gayar O, Timsina P, Nawar N, Eid W. Mobile applications for diabetes self-management: status and potential. Journal of Diabetes Science and Technology 2013;7(1):247-62

20. Liang X, Wang Q, Yang X, Cao J, Chen J, Mo X, et al. Effect of mobile phone intervention for diabetes on glycaemic control: a meta-analysis. Diabetic Medicine. 2011:28(4):455-63.

21. Chomutare T, Fernandez-Luque L, Årsand E, Hartvigsen G. Features of mobile diabetes applications: review of the literature and analysis of current applications compared against evidence-based guidelines. Journal of Medical Internet Research. 2011;13(3).

22. Årsand E, Tatara N, Østengen G, Hartvigsen G. Mobile phone-based self-management tools for type 2 diabetes: the few touch application. Journal of Diabetes Science and Technology. 2010;4(2):328-36.

23. Istepanian RS, Zitouni K, Harry D, Moutosammy N, Sungoor A, Tang B, et al. Evaluation of a mobile phone telemonitoring system for glycaemic control in patients with diabetes. J Telemed Telecare. 2009;15(3):125-8

24. Faridi Z, Liberti L, Shuval K, Northrup V, Ali A, Katz DL. Evaluating the impact of mobile telephone technology on type 2 diabetic patients' self-management: the NICHE pilot study. Journal of Evaluation in Clinical Practice. 2008;14(3):465-9

25. Carroll AE, Marrero DG, Downs SM. The HealthPia GlucoPack ${ }^{\mathrm{TM}}$ Diabetes phone: a usability study. Diabetes Technology and Therapeutics. 2007;9(2):158-64.
26. Demiris G, Afrin LB, Speedie S, Courtney KL, Sondhi M, Vimarlund V, et al. Patient-centered applications: use of information technology to promote disease management and wellness. A white paper by the AMIA knowledge in motion working group. Journal of the American Medical Informatic Association. 2008;15(1):8-13.

27. Al Dahdah M, Du Loû AD, Méadel C. Mobile health and maternal care: A winning combination for healthcare in the developing world? Health Policy and Technology. 2015;4(3):225-31.

28. Daly LM, Horey D, Middleton PF, Boyle FM, Flenady $\mathrm{V}$. The Effect of Mobile App Interventions on Influencing Healthy Maternal Behavior and Improving Perinatal Health Outcomes: Systematic Review. JMIR mHealth and uHealth. 2018;6(8).

29. Feroz A, Perveen S, Aftab W. Role of mHealth applications for improving antenatal and postnatal care in low and middle income countries: a systematic review. BMC Health Services Research. 2017;17(1):704

30. Lee SH, Nurmatov UB, Nwaru BI, Mukherjee M, Gran L, Pagliari C. Effectiveness of mHealth interventions for maternal, newborn and child health in low-and middle-income countries: Systematic review and meta-analysis. Journal of global health. 2016;6(1).

31. Ming WK. Telemedicine Technologies for Diabetes in Pregnancy: A Systematic Review and Meta-Analysis. JMIR research protocols. 2016;18(11):e290.

32. Overdijkink SB, Velu AV, Rosman AN, Van Beukering MDM, Kok M, Steegers-Theunissen RPM. The usability and effectiveness of mobile health technology-based lifestyle and medical intervention apps supporting health care during pregnancy: Systematic review. Journal of Medical Internet Research. 2018;20(4).

33. Poorman E, Gazmararian J, Parker RM, Yang B, Elon L Use of Text Messaging for Maternal and Infant Health: A Systematic Review of the Literature. Maternal and Child Health Journal. 2015;19(5):969-89.

34. Sondaal SFV, Browne JL, Amoakoh-Coleman M, Borgstein A, Miltenburg AS, Verwijs M, et al. Assessing the effect of mHealth interventions in improving maternal and neonatal care in low-and middle-income countries: a systematic review. PloS one. 2016;11(5):e0154664.

35. Archangeli C, Marti FA, Wobga-Pasiah EA, Zima B. Mobile health interventions for psychiatric conditions in children: a scoping review. Child and Adolescent Psychiatric Clinics. 2017;26(1):13-31.

36. Kovács F, Török M, Horváth C, Balogh ÁT, Zsedrovits T, Nagy A, et al. A new, phonocardiography-based telemetric fetal home monitoring system. Telemedicine and e-Health. 2010;16(8):878-82.

37. Meng Q, Song L, Wang X, Fan S, Che L, Zhang G, et al. Development of Health Intelligent Management Cloud Platform on Maternal and Infant Monitor. Zhongguo yi liao qi xie za zhi $=$ Chinese journal of medical instrumentation 2017;41(1):20-2.

38. Noordam AC, Kuepper BM, Stekelenburg J, Milen A. Improvement of maternal health services through the use of mobile phones. Tropical Medicine and International Health. 2011;16(5):622-6.

39. Moher D, Liberati A, Tetzlaff J, Altman DG. Preferred reporting items for systematic reviews an meta-analyses: the PRISMA statement. Annals of internal medicine. 2009;151(4):264-9.

40. Van Ryswyk EM, Middleton PF, Hague WM, Crowther CA. Postpartum sms reminders to women who have experienced gestational diabetes mellitus to test for type 2 diabetes: The diamind randomised controlled trial. Journal of Paediatrics and Child Health. 2015;51:37.

41. McLean A, Osgood N, Newstead-Angel J, Stanley K, Knowles D, Van Der Kamp W, et al. Building research capacity: Results of a feasibility study using a novel $\mathrm{mHealth}$ epidemiological data collection system within a gestational diabetes population. Studies in Health Technology and Informatics. 2017; p. 228-32.

42. Kennelly MA, Ainscough K, Lindsay KL, O'Sullivan E, Gibney ER, McCarthy M, et al. Pregnancy Exercise and Nutrition With Smartphone Application Support: A Randomized Controlled Trial. Obstetrics and Gynecology. 2018;131(5):818-26.

43. Homko CJ, Deeb LC, Rohrbacher K, Mulla W, Mastrogiannis D, Gaughan J, et al. Impact of a telemedicine system with automated reminders on outcomes in women with gestational diabetes mellitus. Diabetes Technol Ther 2012;14(7):624-9.

44. Yang P, Lo W, He ZL, Xiao XM. Medical nutrition treatment of women with gestational diabetes mellitus by a telemedicine system based on smartphones. Journal of Obstetrics and Gynaecology Research. 2018;44(7):1228-34

45. Skar JB, Garnweidner-Holme LM, Lukasse M, Terragn L. Women's experiences with using a smartphone app (the Pregnant plus app) to manage gestational diabetes mellitus in a randomised controlled trial. Midwifery. 2018;58:102-8.

46. Miremberg H, Ben-Ari T, Betzer T, Raphaeli H, Gasnier $\mathrm{R}$, Barda G, et al. The impact of a daily smartphone-based feedback system among women with gestational diabetes on compliance, glycemic control, satisfaction, and pregnancy compliance, glycemic control, satisfaction, and pregnancy
outcome: a randomized controlled trial. American Journal of outcome: a randomized controlled trial.
Obstetrics and Gynecology. 2018;218(4).

47. Mackillop L, Hirst JE, Bartlett KJ, Birks JS, Clifton L, Farmer AJ, et al. Comparing the Efficacy of a Mobile Phone-Based Blood Glucose Management System With Standard Clinic Care in Women With Gestational Diabetes: Randomized Controlled Trial. Journal of Medical Internet Research. 2018;20(3)

48. Rigla M, Martínez-Sarriegui I, García-Sáez G, Pons B, Hernando ME. Gestational diabetes management using smart mobile telemedicine. Journal of Diabetes Science and Technology. 2018;12(2):260-4.

49. Johnson QB, Berry DC. Impacting diabetes self-management in women with gestational diabetes mellitus self-management in women with gestational diabetes $\mathrm{m}$
using short messaging reminders. JMIR mHealth and uHealth. 2018;30(6):320-6

50. Peleg M, Shahar Y, Quaglini S, Fux A, García-Sáez G, Goldstein A, et al. MobiGuide: a personalized and patient-centric decision-support system and its evaluation in the atrial fibrillation and gestational diabetes domains. User Modeling and User-Adapted Interaction.

2017;27(2):159-213.

51. Peleg M, Shahar Y, Quaglini S, Broens T, Budasu R, Fung $\mathrm{N}$, et al. Assessment of a personalized and distributed patient guidance system. International Journal of Medical Informatics. 2017;101:108-30.

52. Nicholson WK, Beckham AJ, Hatley K, Diamond M Johnson LS, Green SL, et al. The Gestational Diabetes Management System (GooDMomS): development, feasibility and lessons learned from a patient-informed, web-based pregnancy and postpartum lifestyle intervention. Bme Pregnancy and Childbirth. 2016;16.

53. Marko KI, Krapf JM, Meltzer AC, Oh J, Ganju N Martinez AG, et al. Testing the Feasibility of Remote Patien Monitoring in Prenatal Care Using a Mobile App and Connected Devices: A Prospective Observational Trial. Jmir Research Protocols. 2016;5(4).

54. Wickramasinghe N, Teoh SY, Mercieca P. Using Smartphones for Accountable Care and Evidence-based Decision Making in Managing Gestational Diabetes: An Australian Case Study. Communications of the Association for Information Systems. 2015;37:705-16.

55. Jo S, Park HA. Development and Evaluation of a Smartphone Application for Managing Gestational Diabetes Mellitus. Healthcare Informatics Research. 2016;22(1):11-21.

56. Mohd Suan MA. Return for Postpartum Oral Glucose Tolerance Test Following Gestational Diabetes Mellitus. Asia-Pacific journal of public health. 2015;27(6):601-9.

57. Hirst JE, Mackillop L, Loerup L, Kevat DA, Bartlett $\mathrm{K}$, Gibson $\mathrm{O}$, et al. Acceptability and user satisfaction of a smartphone-based, interactive blood glucose management system in women with gestational diabetes mellitus. Journal of Diabetes Science and Technology. 2015;9(1):111-5.

58. Teoh SY, Mercieca P, Wickramasinghe N, editors. The use of smart phones for accountable care and evidence-based decision making in the management of gestational diabetes. Proceedings - Pacific Asia Conference on Information Systems, PACIS 2014; 2014.

59. Kaplan R. "Sugamama" - Gestational Diabetes Mobile 'app' innovation in integrated care Proof Of Concept. International Journal of Integrated Care. 2014;14.

60. Grabosch S, Gavard JA, Mostello D. Text4baby improves glycemic control in pregnant women with diabetes. American Journal of Obstetrics and Gynecology. 2014;210(1):S88.

61. Shivanath M, Nayar R, Emmerson C, Loughney A, Purvis A, Fairs A, et al. Will 'simple telehealth' help in the management of women with gestational diabetes? 


\section{JOURNAL of MEDICINE and LIFE}

BJOG: An International Journal of Obstetrics and Gynaecology. 2013;120:111

62. Shea AK, Shah BR, Clark HD, Malcolm J, Walker M, Karovitch A, et al. The effectiveness of implementing a reminder system into routine clinical practice: does it increase postpartum screening in women with gestational diabetes? Chronic Diseases in Canada. 2011:31(2):58-64.

63. Perez-Ferre N, Galindo M, Fernandez MD, Velasco V, Runkle I, de la Cruz MJ, et al. The Outcomes of Gestational Diabetes Mellitus a to Traditional Outpatient Clinic Visits. International Journal to Traditional Outpatient
of Endocrinology. 2010.

64. Wickramasinghe N, Singh M, Troshani I, Hill SR, Hague W, Goldberg S, editors. A pervasive technology solution for diabetes using gestational diabetes as a model. $16^{\text {th }}$ Americas Conference on Information Systems 2010,

AMCIS 2010; 2010

65. Dalfra MG, Nicolucci A, Lapolla A. The effect of telemedicine on outcome and quality of life in pregnan women with diabetes. J Telemed Telecare. 2009;15(5):238-42.

66. Pais S, Parry D, Rowan J, editors. A framework of evaluation of mobile wellness apps for use in a clinical setting. TENSYMP 2017 - IEEE International Symposium on Technologies for Smart Cities; 2017.

67. Kay M, Santos J, Takane M. mHealth: New horizons for health through mobile technologies. World Health Organization. 2011;64(7):66-71.

68. Zvornicanin E, Zvornicanin J, Hadziefendic B. The use of smart phones in ophthalmology. Acta Informatica Medica. 2014:22(3):206

69. Milanese S, Gordon S, Buettner P, Flavell C, Ruston S, Coe $\mathrm{D}$, et al. Reliability and concurrent validity of knee angle measurement: smart phone app versus universal goniometer used by experienced and novice clinicians. Manual therapy 2014;19(6):569-74.

70. Capozzi D, Lanzola G. Utilizing information technologie for lifelong monitoring in diabetes patients. SAGE Publications; 2011.

71. Derbyshire E, Dancey D. Smartphone medical applications for women's health: What is the evidence-base and feedback? International journal of telemedicine and applications. 2013;2013:9

72. Gislason B, McKnight C, Potvin B, Stuart S, Zepeda J, Weber J, et al., editors. Introducing glucofit: An assistive technology for monitoring and managing diabetes. Proceedings - $20127^{\mathrm{th}}$ International Conference on
Broadband, Wireless Computing, Communication and Applications, BWCCA 2012; 2012.

73. Heatley E, Middleton P, Hague W, Crowther C. The DIAMIND study: Postpartum SMS reminders to women who have had gestational diabetes mellitus to test for type 2 diabetes: A randomised controlled trial - study protocol. BMC Pregnancy and Childbirth. 2013;13.

74. Kasmeridis NC, Vassilakopoulos MG, editors. A diet-guide mobile application for diabetes mellitus management. ACM International Conference Proceeding Series; 2015.

75. Kim YJ, Rhee SY, Byun JK, Park SY, Hong SM, Chin SO, et al. A smartphone application significantly improved SO, et al. A smartphone application significantly improved diabetes self-care activities with high user satisfaction.
Diabetes \& Metabolism journal. 2015;39(3):207-17.

76. Mackillop L, Loerup L, Bartlett K, Farmer A, Gibson OJ, Hirst JE, et al. Development of a real-time smartphon solution for the management of women with or at high risk of gestational diabetes. Journal of Diabetes Science and Technology. 2014;8(6):1105-14.

77. O'Sullivan EJ, Kennelly MA, Rokicki S, Ainscough K McAuliffe FM. Cost-effectiveness of a mobile

health-supported lifestyle intervention for preventing gestational diabetes mellitus. American Journal of Obstetrics and Gynecology. 2018;218(1):S380-S1.

78. Pal K, Eastwood SV, Michie S, Farmer A, Barnard ML, Peacock R, et al. Computer-based interventions to improve self-management in adults with type 2 diabetes: a systematic review and meta-analysis. Diabetes Care. 2014;37(6):1759-66.

79. Wickramasinghe N, Gururajan R. Innovation Practice Using Pervasive Mobile Technology Solutions to Improve Population Health Management: A Pilot Study of Gestational Diabetes Patient Care in Australia. Journal for Healthcare Quality. 2016;38(2):93-105.

80. Wu Y, Yao X, Vespasiani G, Nicolucci A, Dong Y, Kwong J, et al. Mobile app-based interventions to support diabetes self-management: a systematic review of randomized controlled trials to identify functions associated with glycemic efficacy. JMIR mHealth and uHealth. 2017;5(3).

81. McMillan B, Abdelgalil R, Madhuvrata P, Easton K, Mitchell C. Reducing the risk of type 2 diabetes mellitus in primary care after gestational diabetes: a role for mobile technology to improve current care. British Journal of General Practice. 2016;66(653):631-2

82. Rasekaba TM, Furler J, Young D, Liew D, Gray K, Blackberry I, et al. Using Technology to Support Care in Gestational Diabetes Mellitus: Quantitative Outcomes of an Exploratory Randomised Control Trial of Adjunc Telemedicine for Gestational Diabetes Mellitus (TeleGDM) Diabetes Research and Clinical Practice. 2018.

83. Given JE, Bunting BP, O'Kane MJ, Dunne F, Coates VE. Tele-Mum: A Feasibility Study for a Randomized Controlled Trial Exploring the Potential for Telemedicine in the Diabetes Care of Those with Gestational Diabetes. Diabetes Technol Ther. 2015;17(12):880-8.

84. Huberty J, Rowedder L, Hekler E, Adams M, Hanigan E, McClain D, et al. Development and design of an intervention to improve physical activity in pregnant women using Text4baby. Translational Behavioral Medicine. 2016;6(2):285-94.

85. Poston L, Bell R, Croker H, Flynn AC, Godfrey KM, Goff L, et al. Effect of a behavioural intervention in obes pregnant women (the UPBEAT study): a multicentre, randomised controlled trial. The Lancet Diabetes \& Endocrinology. 2015;3(10):767-77.

86. Dodd JM, Turnbull D, McPhee AJ, Deussen AR, Grivel RM, Yelland LN, et al. Antenatal lifestyle advice for women who are overweight or obese: LIMIT randomised trial. Bmj. 2014;348:g1285.

87. Jareethum R, Titapant V, Tienthai C, Viboonchart S, Chuenwattana P, Chatchainoppakhun J. Satisfaction of healthy pregnant women receiving short message service via mobile phone for prenatal support: A randomized controlled trial. Journal of the Medical Association of Thailand. 2008;91(4):458-63.

88. Hennemann S, Beutel ME, Zwerenz R. Ready for eHealth? Health professionals' acceptance and adoption of ehealth interventions in inpatient routine care. Journal of Health Communication. 2017:22(3):274-84. 